\title{
Inoculum Density and Expression of Major Gene Resistance to Fusiform Rust Disease in Loblolly Pine
}

\author{
E. G. Kuhlman, Emeritus Scientist, USDA Forest Service, Southern Research Station, Athens, GA 30602; H. V. \\ Amerson, Forest Biotechnologist, and A. P. Jordan, Graduate Student, Department of Forestry, NCSU, Raleigh, \\ NC 27695; and W. D. Pepper, Biometrician, USDA Forest Service, Southern Research Station, Athens, GA 30602
}

\begin{abstract}
Kuhlman, E. G., Amerson, H. V., Jordan, A. P., and Pepper, W. D. 1997. Inoculum density and expression of major gene resistance to fusiform rust disease in loblolly pine. Plant Dis. 81:597600.

Inoculum densities of $25 \times 10^{3}$ to $200 \times 10^{3}$ per $\mathrm{ml}$ of basidiospores from single aeciospore isolates avirulent or virulent to the Fr1 (fusiform resistance-1) gene were used to inoculate a control-pollinated loblolly pine family heterozygous for this gene. With two avirulent isolates, the regression curve of gall frequency 9 months after inoculation went from 26 to $50 \%$ as inoculum density increased to $100 \times 10^{3}$ spores. The regression curve flattened at higher inoculum densities. With two virulent isolates, gall frequency increased from $47 \%$ to a plateau at $97 \%$ as spore density increased. A double-blind element of the study correlated the occurrence of the genetic marker (RAPD marker $\mathrm{J}_{7} \_485 \mathrm{~A}$ ) for Fr1 resistance in haploid megagametophyte tissue and the presence or absence of galls on seedlings after artificial inoculations. With avirulent isolates at the two higher densities of $100 \times 10^{3}$ and $200 \times 10^{3}$, marker presence-absence and phenotypic assessments of gall presence-absence agreed for $95 \%$ of the seedlings. At the $50 \times$ $10^{3}$ level, marker-phenotype agreed for $86 \%$ of the seedlings. The increased marker-phenotype association resulted from a reduction or elimination of disease escapes as Fr1 resistance remained stable even at higher spore densities. The double-blind study indicates that resistant individuals can be identified from the megagametophyte tissue of germinating seedlings. With virulent isolates, marker and disease phenotype did not correlate, even at the lowest inoculum density. The virulent isolates appear to be homozygous for virulence because infection of marker-positive resistant seedlings equaled or exceeded that of marker-negative susceptible seedlings at the lowest inoculum density.
\end{abstract}

Additional keywords: Cronartium quercuum f. sp. fusiforme, Pinus taeda

Fusiform rust disease, caused by Cronartium quercuum (Berk.) Miyabe ex Shirai f. sp. fusiforme, is one of the most important diseases of forest trees in the United States (27). Galls induced by the pathogen on loblolly (Pinus taeda L.) and slash pines (Pinus elliottii Engelm. var. elliottii) result in early mortality, wind breakage, and value loss (3). Resistance to the disease is the most practical means of control $(1,27,35)$. Although the genetic basis of resistance to fusiform rust has long remained uncertain (23), seedling inoculations with basidiospores generated from the aeciospores of mass gall collections

Corresponding author: E. G. Kuhlman; E-mail: fswa/s=g.kuhlman/ou=S33L01A@mhs.attmail.com

The use of trade or firm names in this publication is for reader information and does not imply endorsement by the U.S. Department of Agriculture of any product or service.

Accepted for publication 19 February 1997.

Publication no. D-1997-0423-06R

This article is in the public domain and not copyrightable. It may be freely reprinted with customary crediting of the source. The American Phytopathological Society, 1997. suggest the genetic basis of resistance is polygenic (27). Forest tree breeders have traditionally followed a quantitative approach in breeding for rust resistance, assuming polygenic resistance (36). In contrast, Kinloch and Stonecypher (6) and Carson and Carson (2) suggest that resistance to fusiform rust could be controlled by a few major genes. Inocula generated from single galls indicate that resistance mechanisms vary among loblolly and slash pine families $(5,8-10,22,26,28,30,31,33)$. Using specific rather than mass inocula, Kinloch and Walkinshaw (7) and Nelson et al. (19) propose that resistance in slash pine is based on major genes and follows a gene-for-gene model.

Recently, we $(11,34)$ demonstrated that a DNA marker (RAPD marker $J_{7 \_} 485 A$ ) is significantly associated with resistance to fusiform rust disease in second and third generation progeny of loblolly pine family 10-5 after both artificial and natural infections. The polymorphic marker was tightly linked in coupling with resistance (marker present $=$ resistant, marker absent $=$ susceptible) and denoted a resistance locus or gene termed Fr1. When 386 progeny from four families of 10-5 origin were challenged with inocula avirulent against Fr1,
$98 \%(168 / 171)$ with the $\mathrm{J}_{7} 485 \mathrm{~A}$ marker were phenotypically resistant. However, $24 \%(52 / 215)$ lacking the $\mathrm{J}_{7 \_} 485 \mathrm{~A}$ marker also failed to develop galls. These false positives could have resulted from escape, chance of uneven recombination alone, or unrecognized resistance loci. No other resistance loci were detected. Based on a maximum likelihood approach, escape provided a better theoretical explanation for this group of individuals than did uneven recombination alone (34).

Increasing the inoculum density of a pathogen can have varying effects. If the inoculum is a heterogeneous mix with regard to virulence, increasing the inoculum density can mask the presence of resistance genes in the host plant. With heterogeneous inoculum of $C$. quercuum $\mathrm{f}$. sp. fusiforme, increasing the inoculum density raised the infection frequency and resulted in less discrete differences between resistant and susceptible pine families $(4,15,16)$. Shain and Cornelius (29) indicated that the highest inoculum density of urediospores of a heterogeneous Melampsora medusae isolate was least efficient in causing infection of cottonwood leaves, probably because the spores at the high density were self-inhibiting. The adult plant resistance of Thatcher wheat was sensitive to a high inoculum density of Puccinia graminis var. tritici in field tests (18).

Studies increasing the density of homogeneous inoculum have been less frequently reported. Petersen (20) found that increasing the inoculum density of urediospores of race $15-\mathrm{B}$ of $P$ graminis var. tritici on susceptible Little Club wheat seedlings increased the number of uredial pustules formed, resulting in coalescing of infections. With increasing inoculum, the expression of major gene resistance in potato leaflets to Phytophthora infestans varied from immunity to spreading sporulating lesions over all leaf surfaces (32).

The objectives of this study were twofold. We empirically examined the effect of inoculum density of virulent and avirulent isolates of C. quercuum f. sp. fusiforme on the stability of the Fr1 major gene effect and the reduction in the number of escapes. Second, we conducted the study in a double-blind manner (phenotype and genotype assessments independent) to test whether DNA marker $\mathrm{J}_{7 \_} 485 \mathrm{~A}$, in the absence of phenotypic data, could accurately identify resistant seedlings. 


\section{MATERIALS AND METHODS}

Progeny from control-pollinated loblolly pine family $154-308 \times 4666-4$ were chosen for this study. Tree 154-308 is the result of a cross of $29 R \times 10-5$, two sources of fusiform rust resistance. Tree 10-5 is heterozygous for the Fr1 resistance gene, which is tightly linked to marker $\mathrm{J}_{7 \_} 485 \mathrm{~A}$ (34). Tree 154-308 was heterozygous for marker $\mathrm{J}_{7 \_} 485 \mathrm{~A}$ in a preliminary trial. Open-pollinated progeny of 154-308, when inoculated with mass inoculum, had a gall frequency similar to open-pollinated progeny of 10-5. This finding indicated that 154-308 did not have resistance from $29 \mathrm{R}$ because progeny from $29 \mathrm{R} \times 10-5$ trees with resistance from both parents have gall frequencies less than one-half those of open-pollinated 10-5 progeny (14). The pollen parent $4666-4$ is a highly susceptible loblolly selection (9). Thus, resistance in our control-pollinated family was derived from the seed parent. Factors inherited from the seed parent in conifers can be genetically assessed in the haploid megagametophyte tissue (34).

Seeds were stratified and germinated. Germinating seedlings were removed from germ trays before the seed coats were shed. The megagametophyte tissue was removed from the seed coat, placed in a numbered Eppendorf tube, and immediately frozen at $-80^{\circ} \mathrm{C}$. In correspondingly numbered planting tubes, individual seedlings were planted in Fafard II Mix (Conrad Fafard, Inc., Agaum, MA).

Single aeciospore isolates were produced and reference cultures were stored $(12,21)$. Two pairs of single-aeciospore isolates avirulent (SC 20-21 and SC 35-5) and virulent (NC 2-36 and NC 2-40) to the Fr1 resistance were used to inoculate leaves of individual northern red oak (Quercus rubra) seedlings. Three weeks after inoculation, basidiospores were cast into deionized water adjusted with addition of $\mathrm{HC} 1$ to $\mathrm{pH}$ 2.0. Cast spores were washed in deionized water, and spores of

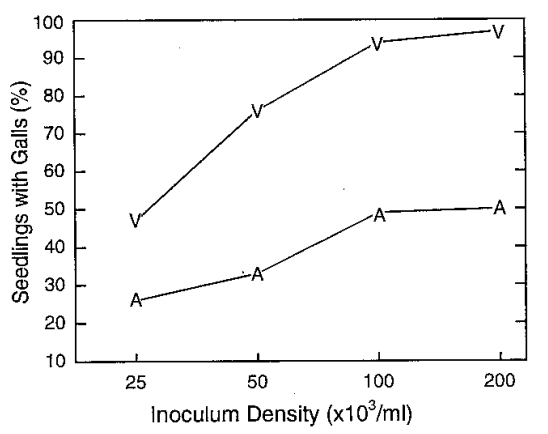

Fig. 1. Graphs of fusiform rust galls on loblolly pine seedlings from family $154-308 \times 4666-4$, 9 months after inoculation with four densities of basidiospores produced from each of two single-aeciospore isolates with virulence or avirulence toward the resistance. Regression of each pair of isolates did not differ significantly, and so data were combined by avirulent (A) and virulent $(\mathrm{V})$ isolates. each isolate were adjusted to concentrations of $25 \times 10^{3}, 50 \times 10^{3}, 100 \times 10^{3}$, and $200 \times 10^{3}$ per ml with a Coulter Model B particle counter (Coulter Electronics, Inc., Hialeah, FL). The four isolate treatments with four concentrations of each were inoculated onto 6-week-old pine seedlings using the concentrated basidiospore spray system (CBS) (17). Each inoculation treatment (isolate $\times$ concentration) flat had 15 seedlings. There were four replications. Some postinoculation mortality reduced the number of seedlings to 10 to 14 per flat. The 16 inoculation treatments were randomized within replications. After seedlings in a single flat were inoculated with one of the inocula, the sprayer was rinsed with $95 \%$ ETOH followed by water before another inoculum was used.

RAPD marker genotype assessments were conducted for marker $J_{7 \_} 485 \mathrm{~A}$ in selected treatments. Avirulent treatments with the lowest inoculum density were not assessed because many disease escapes were expected. Virulent treatments at the two highest inoculum densities were not assessed because most seedlings were galled. DNA extractions and RAPD marker protocols followed procedures described by Wilcox et al. (34). Haploid DNA from megagametophyte tissue was used to determine marker presence or absence. In five instances, damaged megagametophyte tissue did not yield extractable DNA because a $-80^{\circ} \mathrm{C}$ freezer failed. Diploid DNA from needle tissue was substituted in those samples because family 4666-4 does not have the $\mathrm{J}_{7 \_} 485 \mathrm{~A}$ marker $(\mathrm{H}$. V. Amerson, unpublished). Diploid DNA from needles was also used to clarify a few genotypephenotype discrepancies in treatments with avirulent isolates.

Seedlings were examined for the presence of rust galls 3, 6, and 9 months after inoculation. Gall frequency and marker genotype data were collected independently in a double-blind fashion. The 9month data on gall frequency was subjected to regression analysis. Comparisons of marker-phenotype associations were made with Fisher's exact test and a logarithm of odds test (LOD score generated with Mapmaker Macintosh 2.0 software, E. I. DuPont de Nemours and Company, Wilmington, DE).

\section{RESULTS}

The regression analysis indicated the two avirulent and the two virulent isolates did not differ within virulence types; thus we combined data for the two isolates of each virulence type. Nine months after inoculation, galls were present on 26 to $50 \%$ of the seedlings in family $154-308 \times$ 4666-4 that had been inoculated with single-aeciospore isolates avirulent to the Fr1 resistance gene (Fig. 1). Infection by the avirulent isolates increased significantly as the inoculum density increased from $25 \times$ $10^{3}$ to $100 \times 10^{3}$ spores per ml. However, infection remained at the $50 \%$ level with the $200 \times 10^{3}$ spores per ml concentration. The infection level by virulent isolates at the lowest inoculum density was almost twice that of avirulent isolates. Almost all seedlings were infected by the virulent isolates at the two highest inoculum levels.

The double-blind study confirmed the previously reported $(11,34)$ high correlation of the marker $J_{7} 485 \mathrm{~A}$ with resistance in seedlings related to family 10-5 inoculated with isolates avirulent to Fr1 resistance (Table 1). Seedlings of 154-308 $\times$ 4666-4 are third generation 10-5 progeny. With the avirulent isolates (SC 20-21 and SC 35-5), the associations between the marker and seedling resistance were highly significant according to both statistical tests. At the $100 \times 10^{3}$ and $200 \times 10^{3}$ densities with avirulent isolates, marker-phenotype assessments of resistance versus susceptibility agreed for $95 \%$ of the specimens $(184 / 193)$; at the $50 \times 10^{3}$ spore level, marker-phenotype agreement was reduced to $86 \%(88 / 102)$. With isolates virulent to the Fr1 resistance (NC 2-36 and NC 2-40), infection was random at the 25 $\times 10^{3}$ inoculum levels and almost $100 \%$ at

Table 1. Concurrence of phenotypic data (presence-absence of fusiform rust galls 9 months after inoculation with basidiospores of Cronartium quercuum $\mathrm{f}$. sp. fusiforme) with the presence or absence of the $\mathrm{J}_{7} \_485 \mathrm{~A}$ marker for the Fr1 gene in seedlings of family $154-308 \times 4666-4$

\begin{tabular}{|c|c|c|c|c|c|c|c|}
\hline \multirow[b]{2}{*}{ Isolate } & \multirow[b]{2}{*}{ ID $^{\mathbf{a}}$} & \multicolumn{4}{|c|}{ Marker/gall ${ }^{b}$ (no. of seedlings) } & \multirow[b]{2}{*}{ LOD $^{c}$} & \multirow{2}{*}{$\begin{array}{c}\text { Fisher's } \\
\text { exact test }\end{array}$} \\
\hline & & $+/-$ & $-1-$ & $+/+$ & $-/+$ & & \\
\hline \multirow{3}{*}{$\overline{\text { SC } 20-21^{d}}$} & 50 & 25 & 9 & 1 & 19 & 5.02 & $<0.001$ \\
\hline & 100 & 27 & 1 & 2 & 25 & 11.50 & $<0.001$ \\
\hline & 200 & 22 & 0 & 0 & 18 & 12.04 & $<0.001$ \\
\hline \multirow[t]{3}{*}{ SC $35-5$} & 50 & 31 & 4 & 0 & 13 & 8.47 & $<0.001$ \\
\hline & 100 & 24 & 2 & 0 & 23 & 11.12 & $<0.001$ \\
\hline & 200 & 20 & 3 & 1 & 25 & 8.73 & $<0.001$ \\
\hline \multirow[t]{2}{*}{ NC 2-36 } & 25 & 9 & 14 & 20 & 10 & 0.00 & 0.057 \\
\hline & 50 & 4 & 4 & 22 & 22 & 0.00 & 1.000 \\
\hline NC $2-40$ & 25 & 13 & 12 & 15 & 15 & 0.04 & 1.000 \\
\hline
\end{tabular}

a ID = inoculum density $\left(\times 10^{3}\right)$.

b Marker/gall present or absent (+ or - ).

c A logarithm of odds (LOD) value of 3.0 is approximately equal to a $P$ value of 0.001 and indicative of a significant marker-resistance association. LOD values are logarithmic, so that an LOD 4 is 10 times greater than 3 .

${ }^{d}$ Isolates SC 20-21 and SC 35-5 are avirulent, NC 2-36 and NC 2-40 are virulent to the Fr1 gene. 
the two highest levels (Table 1, Fig. 1). At $25 \times 10^{3}$ and $50 \times 10^{3}$, the marker-phenotype associations were nonsignificant in both statistical tests, and seedlings with or without the marker occurred in nearly equal frequency as galled and nongalled phenotypes (Table 1, NC 2-36 at $50 \times 10^{3}$ and NC 2-40 at $25 \times 10^{3}$ ).

Among the avirulent inoculum challenges where marker data were monitored, disease escapes (nongalled-marker negative specimens) were most common at the $50 \times 10^{3}$ spore level, with isolates SC 20 21 and SC 35-5 having, respectively, nine and four such specimens among their 45 marker-negative plants (Table 1), representing 29\% escapes. Across both avirulent inocula, escapes were reduced to approximately $6 \%$ at both the $100 \times 10^{3}$ and $200 \times$ $10^{3}$ levels. In fact, escapes were eliminated with isolate SC 20-21 at the highest density. The frequencies of gall-free plants after inoculation with virulent isolates at the $50 \times 10^{3}$ to $200 \times 10^{3}$ levels were similar to the frequencies of escapes recognized with the avirulent isolates.

Increased inoculum levels with avirulent isolates did not appear to break down resistance. Across the avirulent inocula, only four of 153 seedlings with the $\mathrm{J}_{7-} 485 \mathrm{~A}$ marker became diseased (Table 1), and these were distributed among the three highest inoculum densities $\left(50 \times 10^{3}\right.$ to 200 $\left.\times 10^{3}\right)$.

\section{DISCUSSION}

Stewart (32) suggests that spreading lesions at higher inoculum concentrations of $P$. infestans are caused by major genes that are incompletely expressed. With avirulent isolates, we saw neither incomplete expression nor evidence for polygenic resistance. At the highest inoculum density, the Fr1 locus alone explained the $100 \%$ resistance observed with isolate SC 20-21. We presumed that with avirulent isolates, resistance based on a heterozygous Fr1 gene alone would yield approximately 50\% infection even at the highest inoculum levels. Gall frequency data (Fig. 1) confirmed this hypothesis, and marker data (Table 1) showed that infection was confined almost exclusively to individuals lacking the $\mathrm{J}_{7} 485 \mathrm{~A}$ marker. Because recombinations between the marker and the resistance locus are reported to be $2 \%$ (34), the four observed infections in the presence of the $J_{7 \_} 485 \mathrm{~A}$ marker may be due to recombination alone. These interactions of the avirulent inocula with third generation 10-5 loblolly pine progeny confirm that $\mathrm{Fr} 1$ is a major gene that provides resistance in this pedigree and show that marker selection can accurately identify resistant seedlings.

Earlier studies using the CBS method used inoculum concentrations of $50 \times 10^{3}$ spores per $\mathrm{ml}$ or less. The primary purpose of those studies was to identify pine families resistant to heterogeneous mixes of the rust fungus $(13,22,24-26,28)$. Increasing the inoculum density resulted in weaker separation of resistant and susceptible sources because the heterogeneous mix presumably contained a variety of genes for virulence and avirulence $(15,16)$. When we first identified the $J_{7 \_} 485 \mathrm{~A}$ marker for Fr1 resistance in a study using $45 \times 10^{3}$ spores per $\mathrm{ml}$ inocula and control-pollinated progeny of $10-5$ origin (34), we found many marker negative-nongalled seedlings, believed to be disease escapes. By reducing or eliminating such individuals with higher inoculum densities in this study, we clearly demonstrated that such plants were truly disease escapes. Because disease escapes complicate marker-trait association studies, we will use at least the $100 \times 10^{3}$ spores per $\mathrm{ml}$ inoculum density when seeking additional rust resistance markers.

Single aeciospore isolates are dikaryotic and for a given locus could be either homozygous (virulent or avirulent) or heterozygous with regards to virulence. Designation of an isolate as avirulent (based on marker-phenotype associations) indicates it is homozygous for avirulence. Basidiospores from an isolate homozygous for virulence should be equally pathogenic on seedlings with or without a corresponding resistance gene. In contrast, all basidiospores from isolates heterozygous for virulence would be capable of infecting seedlings lacking the resistance gene, but only the half of the basidiospore population with the virulence gene could infect seedlings with the resistance gene. Thus, at low inoculum densities, heterozygous isolates would infect more plants without the resistance gene than with the gene. With our virulent isolates at low inoculum densities, infection of marker-positive (resistant) individuals equaled or exceeded infection of marker-negative (susceptible) individuals, suggesting the virulent isolates are homozygous for virulence.

\section{LITERATURE CITED}

1. Barber, J. C., and Dorman, K. W. 1957. Slash pine progeny tests indicate genetic variation in resistance to rust. U.S. Dep. Agric. For. Serv., S.E. For. Exp. Stn. Res. Note 104.

2. Carson, S. D., and Carson, M. J. 1989. Breeding for resistance in forest trees - a quantitative genetic approach. Annu. Rev. Phytopathol. 27:373-395.

3. Czabator, F. J. 1971. Fusiform rust of southern pines - a critical review. U.S. Dep. Agric. For. Serv., So. For. Exp. Stn. Res. Pap. SO-65.

4. Griggs, M. M., Dinus, R. J., and Snow, G. A. 1984. Inoculum source and density influence assessment of fusiform rust resistance in slash pine. Plant Dis. 68:770-774.

5. Griggs, M. M., and Walkinshaw, C. H. 1982. Diallel analysis of genetic resistance to Cronartium quercuum f. sp. fusiforme on slash pine. Phytopathology 72:816-818.

6. Kinloch, B. B., Jr., and Stonecypher, R. W. 1969. Genetic variation in susceptibility to fusiform rust in seedlings from a wild population of loblolly pine. Phytopathology 59:1246-1255.

7. Kinloch, B. B., Jr., and Walkinshaw, C. H.
1991. Resistance to fusiform rust in southern pines: How is it inherited? Pages 219-228 in: Rusts of Pine. Proc. IUFRO Rusts Pine Working Party Conf. Y. Hiratsuka, J. K. Samoil, P. V. Blenis, P. E. Crane, and B. L. Laishley, eds. Inf. Rep. NOR-X-317, Edmonton, Canada.

8. Kuhlman, E. G. 1990. Frequency of singlegall isolates of Cronartium quercuum $\mathrm{f}$. sp. fusiforme with virulence toward three resistant loblolly pine families. Phytopathology 80:614-617.

9. Kuhlman, E. G. 1992. Interaction of virulent single-gall isolates of Cronartium quercuum $\mathrm{f}$ sp. fusiforme and resistant families of loblolly pine. For. Sci. 38:641-651.

10. Kuhlman, E. G. 1994. Responses of three Texas loblolly pine families to aeciospore isolates of Cronartium quercuum f. sp. fusiforme. Pages 196-203 in: Proc. So. For. Tree Improve. Conf., 22nd. U.S. Dep. Agric. For. Serv., Atlanta, GA.

11. Kuhlman, E. G., Amerson, H. V., and Wilcox, P. L. 1995. Recent advances in research on fusiform rust. Pages 17-21 in: Proc. IUFRO Rusts Pines Working Party Conf., 4th. S. Kaneko, K. Katsuya, M. Kakishima, and Y. Ono, eds. Forestry and Forest Products Research Institute, Tsukuba, Japan.

12. Kuhlman, E. G., and Matthews, F. R. 1993. Variation in virulence among single-aeciospore isolates from single-gall isolates of Cronartium quercuum f. sp. fusiforme. Can. J. For. Res. 23:67-71

13. Kuhlman, E. G., and Powers, H. R., Jr. 1988. Resistance responses in half-sib loblolly pine progenies after inoculations with Cronartium quercuum f. sp. fusiforme. Phytopathology 78:484-487.

14. Kuhlman, E. G., and Powers, H. R. 1991. Family performance of fusiform rust resistant loblolly pines in a seedling seed orchard. Pages 229-234 in: Rusts of Pine. Proc. IUFRO Rusts Pine Working Party Conf. Y. Hiratsuka, J. K. Samoil, P. V. Blenis, P. E. Crane, and B. L. Laishley, eds. Inf. Rep. NOR-X-317, Edmonton, Canada.

15. Laird, P., and Phelps, R. 1975. Controlled inoculum density enhances sensitivity tests of southern pine seedlings to fusiform rust resistance. Plant Dis. Rep. 59:242-244.

16. Matthews, F. R., Miller, T., and Dwinell, L. D. 1978. Inoculum density: Its effect on infection by Cronartium fusiforme on seedlings of slash and loblolly pine. Plant Dis. Rep. 62:105-108.

17. Matthews, F. R., and Rowan, J. 1972. An improved method for large-scale inoculations of pine and oak with Cronartium fusiforme. Plant Dis. Rep. 56:931-934.

18. Nazareno, N. R. X., and Roelfs, A. P. 1981. Adult plant resistance of Thatcher wheat to stem rust. Phytopathology 71:181-185.

19. Nelson, C. D., Doudrick, R. L., Nance, W. L., Hamaker, J. M., and Capo, B. 1994. Specificity of host:pathogen genetic interaction for fusiform rust disease on slash pine. Pages 403-411 in: Proc. So. For. Tree Improv. Conf., 22nd. U.S. Dep. Agric. For. Serv., Atlanta, GA.

20. Petersen, L. J. 1959. Relations between inoculum density and infection of wheat by urediospores of Puccinia graminis var. tritici. Phytopathology 49:607-614.

21. Powers, H. R., Jr. 1980. Pathogenic variation among single-aeciospore isolates of Cronartium quercuum f. sp. fusiforme. For. Sci. 26:280-282.

22. Powers, H. R., Jr. 1985. Response of sixteen loblolly pine families to four isolates of Cronartium quercuum f. sp. fusiforme. Pages 89-96 in: IUFRO Proc., Rusts of Hard Pines Working Party Conf. J. Barrows-Broaddus 
and H. R. Powers, eds. Georgia Center for Continuing Education, University of Georgia, Athens.

23. Powers, H. R., Jr. 1991. History and major accomplishments of fusiform rust research on southern pines. Pages 39-44 in: Rusts of Pine,

Proc. IUFRO Rusts of Pine Working Party Conf. Y. Hiratsuka, J. K. Samoil, P. V. Blenis, P. E. Crane, and B. L. Laishley, eds. Inf. Rep. NOR-X-317, Edmonton, Canada.

24. Powers, H. R., Jr., and Dwinell, L. D. 1978. Virulence of Cronartium fusiforme stable after 25 years. Plant Dis. Rep. 62:877-879.

25. Powers, H. R., Jr., and Matthews, F. R. 1979. Interactions between virulent isolates of Cronartium quercuum f. sp. fusiforme and loblolly pine families of varying resistance. Phytopathology 69:720-723.

26. Powers, H. R., Jr., Matthews, F. R., and Dwinell, L. D. 1977. Evaluation of pathogenic variability of Cronartium fusiforme on loblolly pine. Phytopathology 67:1403-1407.

27. Powers, H. R., Jr., Schmidt, R. A., and Snow,
G. A. 1981. Current status and management of fusiform rust on southern pines. Annu. Rev. Phytopathol. 19:355-371.

28. Powers, H. R., Jr., and Zoerb, M. 1982. Field resistance of slash pine families affected by interactions with local rust populations. Pages 427-430 in: Proc. Bien. So. Silviculture Conf., 2nd. E. P. Jones, Jr., ed. U.S. Dep. Agric. For. Serv., S.E. For. Exp. Stn. Gen. Tech. Rep. SE-24.

29. Shain, L., and Cornelius, P. L. 1979. Quantitative inoculation of eastern cottonwood leaf tissue with Melampsora medusae under controlled conditions. Phytopathology 69:301304.

30. Snow, G. A., and Kais, A. G. 1970. Pathogenic variability in isolates of Cronartium quercuum from five southern states. Phytopathology 60:1730-1731.

31. Snow, G. A., Matthews, F. R. Nance, W. L., and Foster, G. S. 1990. Effects of pollen source on loblolly pine resistance to Cronartium quercuum f. sp. fusiforme. For. Sci.
36:304-312.

32. Stewart, H. E. 1990. Effect of plant age and inoculum concentration on expression of major gene resistance to Phytophthora infestans in detached potato leaflets. Mycol. Res. 94:823-826.

33. Walkinshaw, C. H., and Bey, C. F. 1981 Reaction of field-resistant slash pines to selected isolates of Cronartium quercuum $\mathrm{f}$. sp. fusiforme. Phytopathology 71:1090 1092.

34. Wilcox, P. L., Amerson, H. V., Kuhlman, E. G., Lui, B. H., O’Malley, D. M., and Sederoff, R. 1996. Detection of a major gene for resistance to fusiform rust disease in loblolly pine by genomic mapping. Proc. Natl. Acad. Sci. 93:3859-3864.

35. Zobel, B., Blair, R., and Zoerb, M. 1971. Using research data - disease resistance. J For. 69:486-489.

36. Zobel, B., and Talbert, J. 1984. Applied Forest Tree Improvement. John Wiley \& Sons, New York. 